\title{
INTRODUCTION: The LABOUR OF RACE
}

\author{
Augustine S.J. PARK ${ }^{1}$
}

¿ his special issue interrogates race as a labour. The "labor of race," writes David Theo Goldberg in his book The Threat of Race (2009:4, emphasis in original), "is the work for which the category and its assumptions are employed to effect and rationalize social arrangements of power and exploitation, violence and expropriation." Race, for Goldberg, is a "foundational code" that has been built by "racial thinkers," that is "the day-laborers, the brick-layers, of racial foundations" (2009:4). Understanding race as a labour underscores the ontological unreality of race, which is now, of course, the constructivist orthodoxy in critical sociologies of race. In other words, conceptualizing race as a labour asserts race as an accomplishment, however unstable: an historical, social, economic, and cultural achievement that designates a constantly shifting political grammar. At the same time, understanding race as a labour, or the labour of race, demands that we ask to what work race is put. Following Zygmunt Bauman's (2004) theorization of "wasted lives," race might be theorized as a method of social ordering.

Bauman understands social ordering as a distinctly modern activity as modernity has been characterized by the proliferation of models of the "good society" (Bauman 2004:11). A "side-effect of order-building," according to Bauman (2004:5, emphasis in original), is the production of "wasted humans" or "wasted lives," "that is the population of those who either could not or were not wished to be recognized or allowed to stay" (Bauman 2004:5). The making of the good society, thus, is contingent on separation and elimination. In Modernity and the Holocaust, Bauman refers to this as the "garden culture" (1989:92) in which the removal and destruction of weeds is not destructive but creative - an aesthetic exercise in design and artifice, while Mary Douglas (2005) describes elimination as a positive effort to re-order and organize an environment. However, Douglas reminds us that nothing is inherently waste, but is assigned or designated as waste. Thus, race can be conceptualized through the lens of social order as the work of design: what is to be cultivated, what is to be separated and eradicated. This special issue represents di-

1. Many thanks to Madalena Santos for her improvements to this introductory essay. 
verse ways of getting at the problem of the labour of race - that is how race is accomplished and to what work race is put - in particular examining race as a methodology of ordering. While all of the authors of this special issue employ different vocabularies, several cross-cutting themes emerge that can be conceptualized as three modalities of the labour of race: race as a labour of securitization, race as a labour of exclusion, and race as a labour of belonging and identity formation.

\section{The Labour of Securitization}

The first set of papers in this issue can be interpreted through the lens of securitization. As an analytic, securitization enables critical interrogation of the object and objective of security, asking who is deemed a threat and to what ends, while at the same time presupposing resistance. As a labour of race, securitization not only accomplishes race, but also mobilizes race as a means of ordering. Race, thus, emerges as a site and strategy of surveilling, managing, governing, but also eliminating populations. In particular, the papers by Bell, Monaghan, and Santos contribute to the growing body of race scholarship that draws on Foucauldian conceptualizations of race and racism (see, for example: Stoler 1995; Kelly 2004; Su Rasmussen 2011). While his genealogy of European racism was never completed (Su Rasmussen 2011:34), Foucault's account of modern racism has garnered increased attention since the English translation of the 1976 Collège de France lectures Society Must Be Defended. Rather than understanding racism as misguided prejudice or ideology, Foucault's concept casts modern racism as a modality of biopolitical government, a form of governmentality (Su Rasmussen 2011:35, 40).

In contrast to sovereign power based on the "right to take life or let live" (Foucault 1990:138; Foucault 1997:241), biopolitics is focused on the regulation of the species body, the optimization of the life of the population, "the right to make live and to let die" (Foucault 1997:241). Racism, for Foucault, is "a way of introducing a break into the domain of life that is under power's control: the break between what must live and what must die" (Foucault 1997:254) by separating groups within a population among good and inferior races or "worthy and unworthy life" (Su Rasmussen 2011:40). Racism, thus, establishes a relation between maximizing the life of the species body and the death of inferior races as biological threats. Racism, in particular state racism, binds the sovereign power of death to biopolitical governance where the death of inferior races - both internal and external — makes life "healthier and purer" (Foucault 1997:255). In their papers, Bell, Monaghan, and Santos in varying ways examine race and racism as forms of biopolitical government in the management of populations employing strategies of securitization. Racialized populations become reproduced as problems and the object of diverse modalities of securitization.

Colleen Bell opens this special issue with an examination of biometrics as a biopolitical strategy of racially coded surveillance that has, with enthusiasm, been taken up in contemporary counter-insurgency, such as the pervasive use of iris scanning and finger printing in Afghanistan and Iraq. Populations in the War on Terror are internally disaggregated with some portions of the population perceived as friendly ("blue" people), while others are perceived as hostile ("red" people) to the US military. However, it is the "grey" population that poses uncertainty and thus an unknown risk. Biometrics, therefore, operate through a racial logic that enacts separation into, on the one hand, a population to be optimized and cultivated and, on the other hand, a threat to be exterminated; and, thus, Bell argues, biopolitical racism "takes hold of life while also enacting death" (Bell:468). As a modality of surveillance, biometrics aim "to offer a new scope of visibility" to determine "greys' anatomy, in both biological and political terms" (Bell:466). While biometrics promise to uncover insurgents hidden amongst the population, the perverse effect is to transform whole populations into potential threats. Relying on the mining and harvesting of massive quantities of biological data, biometrics underscore the biopolitical quality of counter-insurgency that invests control of the population in systematically and administratively "knowing" the population. Yet as a technology that aims, intrusively and without consent, to register the body data of racialized populations, the instruments are strikingly racially coded, engineered with whiteness in mind. Thus, biometric technology — far from neutral — is "both racializing in its application, and also structured on the normalization of whiteness" (Bell:472). At the same time, in the face of northern anxiety about threats from the global south, biometrics can be understood as a form of global, racialized biopolitical power in which western states have unlimited access to the southern populations being documented.

While persistently marked by the labour of securitization, the documentation and surveillance of racialized populations to be managed has assumed different materializations in diverse contexts. Jeffrey Monaghan provides an historical interrogation of "settler governmentality" and the centrality of "racializing surveillance" (Browne 2012) in the categorizing of indigenous populations, which represents an iteration of the same logic of internal disaggregation that Bell identifies and, as in Bell's analysis, specifically problematizes and racializes the potential for (or perhaps danger of) political resistance. Analyzing archived correspondences from the late 1880s of Peter Ballendine, a Métis undercover 
agent of the Department of Indian Affairs, Monaghan examines efforts to eradicate Aboriginal resistance to settler colonial expansionism in the North-West. As a covert operative, Ballendine was part of the settler apparatus of surveillance, in particular tracking the activities of leaders such as Big Bear, Poundmaker, and Little Poplar, as well as reporting on and intervening to disrupt possibilities of organized resistance. Racializing surveillance, which Simone Browne defines as a "technology of social control" that "signals those moments when enactments of surveillance reify boundaries and borders along racial lines" (2012:72), was central first to distinguishing liberal settler society from the illiberal indigenous population to be managed. Second, within the indigenous population, racializing surveillance was key to casting indigenous resistance as a menace to the settler society to be defended. Settler governmentality aimed "to dispossess indigenous peoples of their land and, once reduced to minority populations, target them with strict population management systems" (Monaghan:497). The goal was to transform indigenous populations to conform to settler conduct and values or, in other words, to become liberal. The work of cultivating a new liberal population of "good Indians," however, operated in tandem with a "logic of elimination" (Wolfe 2006) of "bad Indians" in which political resistance to the settler colonial project was cast as a threat to be eradicated.

A mobile rationality, the "logic of elimination," premised on the expropriation of land, annihilation of peoples, and destruction of the social and cultural features of peoples, is inherent in settler colonial projects. While indigenous political resistance is cast as a security threat in Monaghan's settler governmentality, in her contribution, Madalena Santos examines how the Palestinian other is rendered as a demographic and security risk in the settler colonial project of Eretz Israel. The logic of elimination pivots on ridding Palestine of Arab Palestinians operationalized through a "process of ruling" (Santos:523) to which the labour of race is central, not least of which is the accomplishment of race through the recasting as white of Jewish peoples who had been previously marked as racially other in Europe and the accompanying orientalization of Palestinians. Extending the logic of separation identified by both Bell and Monaghan, the Zionist preoccupation with ethno-demography separates Jews from indigenous Palestinians with correspondingly differential citizenship rights, but also enacts an internal disaggregation that separates "good" subjects from "bad" subjects by hierarchically differentiating Palestinian Arabs. Echoing Monaghan's analysis of "good Indians," "good" Palestinian Arabs can be rendered ideologically closer to the "ideal white Jewish Israeli" (Santos:528); however, no matter the hierarchical ranking no Palestinians can own land or become nationals of the state. Thus, as both Monaghan and Santos conclude, even "good" racialized bodies are still subject to the violence of settler colonialism. Further separations are produced or perpetuated through the consolidations of inequalities, such as class inequality, among Palestinians or the physical separation of communities. For Santos, bodies that are "marked as threats" (Santos:532) can be read through "necropolitics (thanatopolitics) or the management of death" (Santos:532), which mirrors the Foucauldian theorization of state racism as the rupture between the biopolitical optimization of life and that which must die. Striving for a Jewish majority state has prompted biopolitical strategies of population management, such as family planning. At the same time, Santos stresses the agency of Palestinians as political actors, which underscores resistance in any project of securitization.

\section{The Labour of Exclusion}

Bell, Monaghan, and Santos in varying ways discuss how race is invested with a logic of elimination, and that race, as an accomplishment, is put to the work of social order. Returning to Bauman's terms, these papers analyze projects of design that produce "wasted lives." Tightly imbricated with the labour of securitization, the second set of papers in this special issue can be interpreted through the lens of exclusion. Sherene H. Razack (2008) describes "casting out" as expulsion from political community; and, indeed, Foucault's fragmented theory of racism does not necessarily entail literal death, but also encompasses "political death" (Foucault 1997:256). While securitization can be read as a biopolitical, racialized labour of managing and optimizing populations, including through separation, distinction, destruction, and death, exclusion is here advanced as a labour of social ordering that defines civilization and citizenship. Civilization is to be cultivated and defended in the face of the incivility of the other by policing the borders of belonging through the "racial structure of citizenship" (Razack 2008:4). As in Bell's analysis, the papers by Olwan, Jeyapal, and Park articulate anxiety about the borderlessness of racialized threats. Like the contribution of Santos in which Jewish Israelis get reconstructed as "native," these papers express the impulse to expunge the designated foreigner. Olwan, Jeyapal, and Park each employ discourse analysis of various forms of media to interrogate exclusion not as (uniquely) the exercise of state racism, but as a profoundly public and participatory labour. Exclusion, in these papers, betrays a preoccupation with the alien body, the (presumed or constructed) foreigner and foreign incivility as a threat. At the same time, the discourse of alien incivility becomes an important resource for 
defining and reaffirming the civility of the social order to be defended, where the illiberality of the other is treated as a counterpoint to shore up the liberal society.

Indeed, Dana Olwan's contribution examines "honour killings" as a chief discourse in constructing the racialized other, while reproducing and buttressing dominant constructions of Canada as a multicultural, liberal democracy. Honour killing prior to $9 / 11$ had been constituted in the media as a distant problem - the very foreignness of which became a means to "bolster notions of cultural superiority and redraw the civilizational line" between the "barbaric" Muslim world and the democratic West (Olwan:550). This dichotomous construction not only tacitly assumed that Canadian women live free from gendered and sexualized violence, but also worked to reproduce monolithic constructions of Muslim majority states, specifically, denying active feminist organizing by local women. From a transnational problem "over there" to a problem brought "home," Olwan employs an analysis of geographical scale to trace the adoption of honour killing as a motif in media and state discourse as a foreign pathology that has been imported to Canada. Honour killing as a discourse, in the labour of race, not only works to constitute the other, but also does the work of defining social order. Thus, exemplified by the Shafia murders, honour killing discourse asserts the limits of multiculturalism. Here, Canada is advanced as a multicultural haven, free of racism, governed by equality and the rule of law, and offering lives of freedom to racialized others who - like the Shafia daughters - choose to "Canadianize"; yet, the discourse of honour killing simultaneously serves as a boundary between "real Canadians and conditional ones" (Olwan:556), underscoring the precariousness of belonging for racialized populations. State discourse, most notably in the new citizenship guide, employs ostensibly feminist language to veil racialized assumptions that construct Muslim women's bodies as "the ideological and political boundaries of the nation state" (Olwan:558). Their dead bodies meanwhile are mobilized to "script visions of gender equality" (Olwan:561) that come to stand in for Canada in contrast to the violence of the cultural other to be cast out.

Drawing on the work of Sara Ahmed (2000), Daphne Jeyapal provides an examination of media framing of the 2009 Tamil diaspora protests against the genocide of Tamils in the long-standing conflict in Sri Lanka as a "strange encounter." For Ahmed, the stranger is not the unknown body; rather, some bodies are cast as strangers and constituted as dangerous and threatening simply by virtue of their co-presence. According to Jeyapal's analysis, media discourses advanced in news reports, columns, and by readers that constituted the strange encounter were marked by tensions and contradictions, and were - as in Olwan's analysis - shaped by the geographic scale of distance and proximity, as well as the juxtaposition of the alien other and a liberal Canadian order to be defended. On the one hand, media discourses constructed Canada through the value of humanitarianism, while constructing Tamil protesters as insufficiently Canadian by virtue of ongoing involvement with the politics of their "homeland." On the other hand, media discourses constructed Canada as a space of democratic rights while demonizing the Tamil protests as both inconvenient and an infringement of the "right" of "ordinary Canadians" to occupy public spaces unhindered. Here an equivalence is drawn between a smooth commute to work and political rights to protest; thus, the citizenship to which Tamil protesters were deemed to be entitled was radically abrogated. Tamil protests, rather than being taken as a sign of liberal democracy, were cast as mobs, with Tamils homogeneously depicted as terrorists and likened to animals. At stake, then, is who may occupy public spaces, with racialized bodies "marked as trespassers" (Jeyapal:576). What is conveyed in the media discourse is "governmental belonging," which Hage defines as the power to decide "who should feel at home in the nation and how, and who should be in and who should be out, as well as what constitutes too many" (Hage 2000:46, cited in Jeyapal:580). The protests presented an encounter that became a site of defining the liberal self, the social ordering to be protected by the labour of race, and the stranger who is designated as out of place by virtue of his mere proximity.

The stranger, or the outsider, thus, is defined by co-presence. The outsider, indeed, is inside of a space to which he is deemed not to belong. Just as Jeyapal analyzes Tamil diaspora protesters as "strangers," Park examines how racialized citizenship designates "outsiders" within the Canadian polity through racial-nationalism, which combines cultural racism with a logic of pure exclusion (Hage 2006). Cultural difference is reified and mobilized as a methodology for sorting out who is to be excluded. While Jeyapal points out that various voices in the media aimed to abridge the citizenship rights of protesters, Park demonstrates that there are several allegorical figures that have come to organize citizenship discourses in online reader response to news reporting on government action. In response to news reporting the government ban on face coverings at the Oath of Citizenship, the "recalcitrant alien," manifest as the threatening yet victimized, veil-wearing Muslim woman, is defined as an irredeemable cultural other who resists assimilation while making claims to Canadian citizenship. The "citizen of convenience" seeking evacuation from troubled foreign spaces is constituted as "absentee, disloyal, and inassimilable" (Park:609) — a "fake" Canadian in contrast 
to what Olwan terms "real" Canadians, or what Jeyapal calls "ordinary Canadians." Finally, in response to government efforts to crack down on citizenship fraud, commentators constitute all racialized citizens as frauds. In contrast to the alien other to be expelled, Canada is defined according to the script of the open society myth: a haven of multiculturalism, social justice, and generosity. However, just as Olwan identifies the discursive suspicion of multiculturalism, commentators overwhelmingly identify the open society as an Achilles' heel exploited by the unscrupulous other, and thus advance a competing conception of Canadianness that is "white" and neoliberal, demanding self-reliance as a prerequisite for citizenship. Race, as a labour, therefore is mobilized not only to construct the figure of the other to be expelled, but to discursively affirm a dominant identity as an open society while forging a social order that denies the benefits of the open society to designated outsiders.

\section{The Labour of Belonging and Identity Formation}

The contributions by Olwan, Jeyapal and Park analyze the labour of exclusion that works both to accomplish race by designating the foreign threat, and to define the social order to be defended. The contours of the social order identified by all three authors trace an image of liberal democracy and multiculturalism, which is continuously abrogated in response to the constructed incivility of the designated alien. While these authors focus on subjects to be cast out, the stranger, or the outsider, the final set of papers in this special issue focus in complicated ways on the insider, and how the labour of belonging (or, perhaps, exclusionary inclusion) accomplishes race through identity formation. The "politics of belonging as "the dirty work of boundary maintenance"" separates "the world population into 'us' and 'them"” (Yuval-Davis 2006:204) and thus is central to the work of constructing identities.

David Moffette's analysis extends Olwan and Park's discussions, in particular, by examining multiculturalism or convivencia in Ceuta, a Spanish border town located in North Africa with a population composed of a large and growing Muslim minority and a dominant Spanish Christian group fearful of demographic displacement. Rather than "an ideal of tolerance or a mask for a racist order" (Moffette:624), Moffette argues that the concept of convivencia rests simultaneously on tolerance and racism, where tolerance serves as a "regime for governing differences," while reproducing "a pacified and racialized social order" (Moffette:624). Indeed, tolerance, which implies the presence of something dangerous or contaminating, is the privilege of the dominant group to extend. Convivencia serves, centrally, as a resource for identity forma- tion, and affirming the identity of Ceuta as a Spanish city based on longstanding myths of racial inclusion, while at the same time securing the dominance of Christian Ceuties culturally, politically, and economically. Thus, Moffette's paper addresses race as a labour of belonging and, in particular, a defined ideology of inclusion (shot through with inequalities) upon which identity is constructed. However, Moffette's paper also bridges the first and second themes in this special issue by analyzing the precariousness of the convivencia and securitization. Threatened not only by the growth of the local Muslim population, Ceuta is also confronted by unauthorized migrants attempting to cross into Europe. In contrast to porteadores, undocumented porters whose circulation across borders is tacitly supported, migrants are framed as a menace to social order and are cast through a logic of securitization as "potential delinquents, criminals, sexual predators or vectors of disease" (Moffette:637). At the same time, migrants must be subject to exclusion from the inclusive order of convivencia.

Kate Cairns, in her contribution, likewise examines the complex dynamics of identity formation for white Canadian rural youth. Like Moffette and Jeyapal, Cairns proposes a distinctly spatial analysis of race and racialization, interrogating the underexamined space of Canadian rurality. Race as a labour of belonging accomplishes both whiteness and alterity in the rural; at the same time, out of the rural an idealized Canada is produced, rooted in romantic settler-frontier mythologies of racial purity and connection to nature, that makes wasted lives of racialized others. Paradoxically, images of a progressive, urban cosmopolitan Canada threaten to make waste of rural subjects, cast as stagnant and anachronistic. While rurality is coded white, the pathologizing of rural spaces works to support white supremacy by mobilizing class to distance a superior whiteness from "white trash" and "rednecks." Cairns' ethnographic research demonstrates that, using race as a resource, white rural youth actively construct their identities in complex ways. Dirt occupies a tense and paradoxical relationship to youth identity construction. On the one hand, youth are aware of the competing dominant construction of the rural space as poor and backwards and the corresponding rendering of rural populations as "dirty": unclean, undesirable, and degenerate. On the other hand, the youth construct their identities in opposition to imagined dirty urban and transnational spaces marked by danger and racial alterity. Indeed, danger is signified by racial difference. Despite the disparagement of rurality, youth recuperate their identities by closely aligning their self-identities with the rural idyll, which reflects nostalgic conceptualizations of Canada as a space of wilderness, peace, and safety, as well as a community of belonging. Thus, these youth carve out a space 
for themselves as belonging to the Canada of settler-colonial myth belied, of course, by analyses like Monaghan's — by grounding their identities in rurality.

The dynamic relationship between belonging and alterity may be further complicated when definitions of self-identity mobilize race to affirm constructions of alterity. Closing this special issue, Heather Schmidt's contribution examines Confucius Institutes (CIs) in Canada - statesponsored institutes which disseminate Chinese culture globally, particularly in the West. As a kind of "branding campaign" (Schmidt:681), CIs are part of a larger project of "soft power" that aims to foster affection for China through encouraging affective participation in Chinese culture. Schmidt, like Bell, is explicit in understanding race and racialization as a global project; and, like Olwan, Jeyapal, and Park, Schmidt's analysis focuses on the presence of the foreign other in the Canadian nation-space, while shifting the analytic gaze to the modalities of constructing identity mobilized by the other. CIs represent a complex site in which racialized constructions of a western Self intersect with Chinese constructions of both Self and western Other. For CI programs, the "preferred" other is the white westerner. White bodies, indeed, become "necessary" to the CI project. CIs aim to transform western perception of China as an authoritarian and underdeveloped other ("dirty," "weird," and less intelligent as Cairns' young interviewees perceive China), which does not reflect the modern China of today imagined by Schmidt's CI interviewees. Yet, given the prevalence of the "China rising" discourse, today's China is also cast as a threat to western centrality and dominance. As an apparent paradox, therefore, CIs promote traditional Chinese culture in efforts to shift perception of modern China. The focus on Chinese antiquity works both to mitigate western anxiety about displacement by a powerful China and to convey Chinese values and ideas through participation in Chinese cultural practices such as calligraphy. CIs, thus, operate "between two regimes of value": reorientality, which involves the "purposeful recycling of orientalist tropes of China" and reorientalism, which attempts to "redefine China on its own terms" (Schmidt:687). Ultimately, however, one of the effects of CIs is the normalization of whiteness and the consumption of the ethnic other, which reinforces the work of multiculturalism in Canada as examined by Olwan, Jeyapal, and Park.

The papers that make up this special issue in varying ways take on the labour of race, analyzing in diverse contexts the making of race, or its accomplishment, while unpacking the complex and contradictory work to which race is put. In particular, the papers in this issue highlight the ways in which race - an unstable construction - is mobilized in producing and protecting social orderings that manage populations deemed security threats through government and elimination, that exclude aliens while crafting and affirming the society to be defended, and that are organized through the politics of belonging that contribute fundamentally to constructing identities.

\section{REFERENCES}

Ahmed, Sara. 2000. Strange Encounters: Embodied Others in Post-coloniality. London and New York: Routledge Publishing.

Bauman, Zygmunt. 1989. Modernity and the Holocaust. Cambridge: Polity. 2004. Wasted Lives: Modernity and Its Outcasts. Cambridge: Polity.

Browne, Simone. 2012. Race and surveillance. Pp. 72-79 in K. Ball, K. Haggerty, and D. Lyon, eds., Handbook on Surveillance Studies. New York: Routledge.

Douglas, Mary. 2005. Purity and Danger: An Analysis of Concepts of Pollution and Taboo. New York: Routledge.

Foucault, Michel. 1990. The History of Sexuality: An Introduction, Volume 1. New York: Vintage.

1997. 'Society Must Be Defended': Lectures at the Collège de France, 1975-1976. New York: Picador.

Hage, Ghassen. 2006. Insiders and outsiders. In P. Beilharz and T. Hogan, eds., Sociology: Place, Time and Division. London: Oxford University Press.

Goldberg, David Theo. 2009. The Threat of Race: Reflections on Racial Neoliberalism. Malden, MA: Wiley-Blackwell.

Kelly, Mark. 2004. Racism, nationalism and biopolitics: Foucault's Society Must Be Defended. Contretemps 4:58-70.

Razack, Sherene H. 2008. Casting Out: The Eviction of Muslims from Western Law and Politics. Toronto: University of Toronto Press.

Stoler, Ann Laura. 1995. Race and the Education of Desire: Foucault's History of Sexuality and the Colonial Order of Things. Durham, NC: Duke University Press.

Su Rasmussen, Kim. 2011. Foucault's genealogy of racism. Theory, Culture and Society 28(5):34-51.

Wolfe, Patrick. 2006. Settler colonialism and the elimination of the Native. Journal of Genocide Research 8(4):387-409.

Yuval-Davis, Nira. 2006. Belonging and the politics of belonging. Patterns of Prejudice 40(3):197-214. 
